\section{US wins round in patent row}

Washington

A US Claims Court last week dismissed a suit brought by the Institut Pasteur in Paris against the United States - representing its National Cancer Institute (NCI) - over the development of a blood test for antibodies to the virus causing acquired immune deficiency syndrome (AIDS). Lawyers for the French research institute expressed confidence that the claims court decision would be reversed on appeal. But the legal issues raised by the Pasteur lawsuit may have a chilling effect on all international exchange of research materials.

Pasteur's case is based on a form signed by Mikulas Popovic, a colleague of Robert Gallo at NCI, when he accepted samples of a virus being studied at Pasteur by Luc Montagnier.

On 15 September 1983, Montagnier presented data at a Cold Spring Harbor symposium attended by Gallo and Popovic about a virus he called LAV. At the time, both Gallo and Montagnier were looking at a retrovirus as a possible causative agent for AIDS. On 23 September, one week after the Cold Spring Harbor meeting, Popovic signed a receipt accepting two isolates of LAV (Mkt-1B and JBB LAV) as well as anti-interferon sheep serum. The receipt stipulated that these materials would be used only for biological, immunological and nucleic acid studies, and would not be used for "industrial purposes without the prior written consent of the Director of the Pasteur Institute". NCI and Gallo have maintained that they adhered to those conditions. But Pasteur's lawsuit claims that Gallo and his associates used the LAV isolates in research that has since led to development of a commercial diagnostic test kit.

The claims court refused to decide the issue of whether the LAV isolates were used improperly. Instead, Judge James Merow based his ruling on whether or not the document Popovic signed constituted a contract with the United States. NCI argued that neither Popovic nor Gallo had authority to commit the United States to a binding contract. The court decided that even if the receipt did constitute a contract, the French institute had not followed appropriate procedures for settling contract disputes - in this case first submitting a claim to the Department of Health and Human Services - and dismissed the case.

James Swire, a lawyer for the Institut Pasteur, described the ruling as "roadblock, nothing more". Swire says it is a "sad day for international scientific research" when NCI disavows agreements of its principal investigators.

Reaction from the Department of

\section{Eureka}

Health and Human Services was low key. A spokesman said the department was "pleased" by the court's ruling, and expressed hope that it would "provide impetus to resolving this matter". The claims court decision has no direct effect on a separate proceedings being conducted by the US Patent Office on a disputed patent claim for the AIDS antibody blood test (see Nature 320, 96; 1986). The Patent Office has awarded a patent to Gallo for his version of the blood test, but that patent could revert to Montagnier and the Institut Pasteur pending the outcome of the proceedings.

The claims court decision raises important questions about the legal standing of documents signed by researchers when exchanging research materials. J. Edward Rall, deputy director of the National Institutes of Health (NIH) for intramural re-

search, says collaborative agreements are usually entered into on a person-to-person basis. But Rall says most researchers at $\mathrm{NIH}$ are aware that there are certain documents they cannot sign.

In 1981, NIH associate director Philip Chen drafted a sample response for NIH scientists to use when requested to sign agreements accompanying cell lines. Researchers must reply that they cannot sign agreements containing waivers or indemnification agreements. They can, however, promise not to share the cell lines without permission from the supplying laboratory.

Scientists have not had to worry about the legal aspects of cooperation before. Both Chen and Rall say litigation is making some grow wary. Rall worries that if things grow worse lawyers may "subvert straightforward scientific collaboration" with legal arguments that will not be appreciated. "It may be that no one will sign anything any more", says Chen.

Joseph Palca

\title{
Soviets feel left out of Europe
}

THE Eureka conference in London last month revealed a stance contrary to the Helsinki Accords, according to the official Soviet media. The "obvious tendencies" among participants to limit participation in scientific and technological cooperation to West European countries is seen, at best, as an impediment to the close contacts between countries irrespective of political orientation that were the goal of the Final Act, and at the worst as a means of diverting the supposedly peaceful Eureka programmes for military ends.

Much play has been made of an alleged French distinction between Eureka and the US Strategic Defense Initiative (SDI): SDI is a programme which has a civilian application, while Eureka is a civilian programme capable of a military application.

According to the official Soviet newsagency TASS, Western "political and industrial circles" have recently shown increased interest in the "military aspects of Eureka", while Aleksandr Bovin, a Moscow commentator, stressed that such "giants" as Siemens, Philips and Thomson want to take part simultaneously in both Eureka and SDI. There have been indications in the world press, Bovin said, that Bulgaria, Hungary, Czechoslovakia, Yugoslavia and East Germany are interested in working "within the Eureka framework", but the Western countries do not wish to admit countries that do not share their "ideas about the supreme values".

The Soviet stance may be due partly to pique. In their own opinion, as an eminent Soviet arms control expert, General Nikolai Chervov, stressed at the Royal
Institute of International Affairs last week, the Soviets have made a major concession to the West by softening their demands on SDI: instead of requiring that any arms control treaty outlaw all SDIrelated research, they will now accept the compromise that such research be confined to the laboratory stage. Apart from some ironic questions about what, in the context of SDI, constitutes a laboratory, there has been virtually no Western response to this concession.

As for the alleged wish of the West to exclude the socialist countries from Eureka, the problem is a far wider one than a single programme. The whole idea of Eureka, as Bovin rightly noted, is to deal with leading edge technologies lasers, computers, robots and biotechnology - precisely the fields affected by the Co-Com embargo on technology transfer. Furthermore, even if Eureka does include some programmes that would not come under Co-Com, the Socialist countries cited by Bovin have been remarkably quiet about their wish to participate.

The exception in the socialist bloc is East Germany whose leader, Erich Honecker, has publicly expressed some interest in participation, possibly within the framework of the existing intraGerman trade arrangements, and, to a lesser extent, Yugoslavia (which technically ranks as a non-aligned country), where an initial interest now seems to have been replaced by a tacit acknowledgement that, in its state of endemic economic crisis, the country simply cannot afford to participate.

Vera Rich 